\title{
Long-term testosterone treatment prevents gonadal and adrenal tumorigenesis of mice transgenic for the mouse inhibin-a subunit promoter/simian virus $40 \mathrm{~T}$-antigen fusion gene
}

\author{
Rilianawati, J Kero, T Paukku and I Huhtaniemi \\ Department of Physiology, University of Turku, Kiinamyllynkatu 10, 20520 Turku, Finland \\ (Requests for offprints should be addressed to I Huhtaniemi; Email: ilpo.huhtaniemi@utu.fi)
}

\begin{abstract}
We have developed a transgenic (TG) mouse model for tumorigenesis of gonadal somatic cells using a $6 \mathrm{~kb}$ fragment of the mouse inhibin- $\alpha$ subunit promoter (Inh- $\alpha$ ) fused with the simian virus $40 \mathrm{~T}$-antigen (Tag) coding sequence. Gonadal tumors, of Leydig or granulosa cell origin, develop in the TG mice with 100\% penetrance by the age of 5-8 months. Conspicuously, if the mice are gonadectomized, they develop adrenal tumors. Gonadal and adrenal tumorigenesis in these mice seem to be gonadotropin dependent. On the other hand, testosterone stimulates the proliferation of a cell line (Ca1) established from one of the adrenal tumors. The purpose of the present study was therefore to investigate further whether testosterone affects the growth of these gonadal and adrenal tumors in vivo.

Two experimental models were used: (1) Tag TG/ hypogonadotropic $(h p g)$ double mutant mice and (2) castrated Tag TG mice. Both were treated between 1-2 and 7-8 months of age with Silastic rods (length $2 \mathrm{~cm}$ ) containing testosterone. None of the control or testosterone-treated Tag/hpg mice developed gonadal or adrenal tumors. The castrated Tag TG mice displayed, upon microscopical examination, early stages of adrenal

tumors, whereas those receiving testosterone did not show such changes. Testosterone increased the weights of gonads in the Tag/hpg mice, and those of uteri and seminal vesicles in both groups. In contrast, the adrenal weights were significantly reduced in both groups by testosterone treatment. Gonadal histology of the testosterone-treated mice showed hyperplasia of testicular Leydig cells and ovarian stroma. Spermatogenesis was induced by testosterone in the Tag/hpg mice. Adrenal histology of the testosterone-treated animals demonstrated the disappearance of the X-zone. Serum levels of FSH in testosteronetreated $\mathrm{Tag} / \mathrm{hpg}$ mice were significantly increased, while those of serum LH were decreased.

In conclusion, the present result indicate that the suppression of gonadotropins by testosterone implants in castrated Inh- $\alpha /$ Tag TG mice prevents the tumorigenesis of their adrenals. In intact $\mathrm{Tag} / \mathrm{hpg}$ mice, testosterone implants were not able to induce gonadal or adrenal tumorigenesis. Although testosterone treatment was able to induce interstitial cell hyperplasia in gonads of the Inh- $\alpha /$ Tag mice, direct gonadotropin action is responsible for gonadal and adrenal tumorigenesis.

Journal of Endocrinology (2000) 166, 77-85
\end{abstract}

\section{Introduction}

Elevated levels of gonadotropins may promote the development of ovarian and testicular cancer (Biskin \& Biskin 1944, Matzuk et al. 1992). Accordingly, a number of studies support a causal relationship between high levels of gonadotropins and development of cancer in human ovarian epithelium (Gardner 1955, Murphy \& Beamer 1973, Parmar et al. 1988, Manetta et al. 1995), breast (Yano et al. 1992) and prostate (Korkut et al. 1991, Szepeshazi et al. 1991). In accordance, the suppression of circulating gonadotropins by gonadotropin-releasing hormone $(\mathrm{GnRH})$ agonist or antagonist inhibits tumor growth in nude mice bearing ovarian tumor xenografts (Peterson
\& Zimniski 1990, Yano et al. 1994), in $W^{x} / W^{v}$ mice (Blaakaer et al. 1995), in T-antigen (Tag)-expressing transgenic (TG) mice, as well as in crosses of the latter with gonadotropin-deficient $(h p g)$ mice (Kananen et al. 1997). Gonadotropin dependence of certain gonadal tumors is also supported by in vitro studies demonstrating that gonadotropins stimulate the proliferation of Leydig (Czerwiec et al. 1989), ovarian (Simon et al. 1983), and adrenal (Rilianawati et al. 1998) tumor cells.

We have produced a TG mouse model for tumorigenesis of gonadal somatic cells, using a $6 \mathrm{~kb}$ fragment of the mouse inhibin- $\alpha$ subunit promoter (Inh- $\alpha$ ) fused with the simian virus 40 (SV40) Tag coding sequences (Kananen et al. 1995, 1996a). Gonadal tumors, originating 
from Leydig or granulosa cells, develop by the age of $5-8$ months with $100 \%$ penetrance. Recently, we have shown that (1) gonadectomy of the TG mice results in adrenocortical tumorigenesis (Kananen et al. 1996b), (2) testosterone stimulates the proliferation of an established cell line, C $\alpha 1$, originating from one of the adrenal tumors (Rilianawati et al. 1998) and (3) gonadal tumorigenesis and tumor progression in the TG mice are dependent on gonadotropins, as revealed by their inhibition by GnRHantagonist treatment or by crossbreeding of the Tag mice to the hypogonadal mutant $(h p g)$ mouse genetic background (Kananen et al. 1997). Besides dependence on gonadotropins, the possibility also exists that gonadotropinstimulated steroidogenesis, e.g. production of testosterone, or another gonadal factor, is ultimately responsible for the gonadal and adrenal tumorigenesis of the TG mice. Therefore, the purpose of the present study was to investigate whether testosterone itself, in the absence of high gonadotropin levels, could stimulate gonadal and adrenal tumor growth in vivo in the TG mice. Two in vivo models were used: (1) Tag/hpg double mutant mice (low gonadotropin leves with intact gonads) and (2) castrated Tag TG mice (high gonadotropin levels without gonads). Both were implanted with Silastic rods containing testosterone, to achieve blockage of gonadotropin secretion and high circulating testosterone levels.

\section{Materials and Methods}

\section{Experimental animals}

The mice used in these studies were males and females of IT6-M and IT6-F lines of the Inh- $\alpha /$ Tag TG mice, as described before (Kananen et al. 1995), and male and female hpg mice (Cattanach et al. 1977). The hpg mice were purchased from Jackson Laboratory (Bar Harbor, ME, USA). Genotyping of the mice was performed by tail DNA PCR as described earlier (Lang 1991, Kananen et al. 1995). The mice were housed four to six per cage, after weaning at the age of 21 days, in a room with controlled light (12 h light:12 $\mathrm{h}$ darkness) and temperature (21 \pm $\left.1{ }^{\circ} \mathrm{C}\right)$. They were fed with mouse chow SDS RM-3 (Special Diet Service; E, soy-free; Whitman, Essex, UK) and tap water ad libitum. In addition, the mice were maintained in specific pathogen-free conditions. All the procedures using mice were approved by the University of Turku Ethical Committee on Use and Care of Animals.

Rod implants (length $2 \mathrm{~cm}$ ) filled with testosterone (from Sigma, St Louis, MO, USA or Fluka, Buchs, Switzerland) were prepared from Silastic tubing (inner diameter $1.98 \mathrm{~mm}$; outer diameter $3.18 \mathrm{~mm}$; Dow Corning, Midland, MI, USA, catalog No. 602-305) and sealed at both ends with Silastic adhesive (Dow Corning, 7-2947, catalog No. 890). Avertin anethesia (Hogan et al. 1994) was used during the surgical procedures and, for postoperative analgesia, buprenorphine $(0.3 \mathrm{mg} / \mathrm{kg}$, s.c. $)$ was administered.

\section{Hpg experiment}

In the first mating, TG males of IT6-M and IT6-F lines were crossbred with females heterozygous for the $h p g$ mutation (HT females). TG males heterozygous for $h p g$ (Tag/HT males) derived from the first mating were further crossbred with HT females to produce the hypogonadal transgenic (Tag/hpg) double mutant mice, as described earlier (Kananen et al. 1997). These mice (12 females and 15 males) were implanted with the Silastic rods (see above) containing testosterone at 2 months of the age, and killed 6 months after implantation. Non-treated $\mathrm{Tag} / \mathrm{hpg}$ mice (10 females and 10 males) served as controls.

\section{Experiment with castrated TG mice}

TG mice of both lines, IT6-F and IT6-M (16 females and 14 males), were castrated at approximately 4 weeks of age and inserted at the same time with testosterone implants. Castrated non-treated TG mice served as controls (9 females and 8 males).

At the age of 7-8 months, i.e. 6 months after insertion of the testosterone implants, the mice were anesthetized with avertin, and the body weights were recorded. Blood samples were collected into heparinized syringes by cardiac puncture. Blood was allowed to clot overnight at $4{ }^{\circ} \mathrm{C}$ and centrifuged $(300 \mathrm{~g})$ at room temperature to separate serum. The sera were stored at $-20{ }^{\circ} \mathrm{C}$ until analyzed. The gonads, adrenal glands, uteri and seminal vesicles were dissected out, weighed, and snap-frozen in liquid nitrogen for RNA isolation, or fixed in Bouin's solution for histological analyses.

\section{Pituitary and serum hormone measurements}

Luteinizing hormone (LH) levels in sera and pituitary homogenates were measured by an immunofluorometric assay (IFMA) for rat LH (Delfia; Wallac OY, Turku, Finland), as described previously (Haavisto et al. 1993). The sensitivity of the assay was $0.02 \mathrm{ng} / \mathrm{ml}$. Folliclestimulating hormone (FSH) levels in sera and pituitary homogenates were measured by an IFMA for rat FSH, essentially as described before (Hakola et al. 1997), with a new pair of antibodies: an anti-human FSH $\beta$ monoclonal antibody (FSH 56 A) as capture antibody and a polyclonal anti-human $\alpha$-subunit antibody (R93-2705) as signal antibody (van Casteren et al. 2000). Both were donated by Dr W Schoonen (Organon, Oss, The Netherlands). The intra-assay coefficient of variation (C.V.) of the assay was less than 3\% (at rat FSH concentration $4 \mathrm{ng} / \mathrm{ml}$ ), and the interassay C.V. 9.0\% (at rat FSH concentration $4 \mathrm{ng} / \mathrm{ml}$ ). The analytical sensitivity of the assay (signal at 0 standard \pm 2 s.D.) was $0.02 \mathrm{ng} /$ tube which corresponds to 
Table 1 Weights of gonads, uterine/seminal vesicles, and adrenal glands of the Tag/hpg and castrated TG mice with and without testosterone (T) implants. Values are means \pm S.E.M

\begin{tabular}{|c|c|c|c|c|}
\hline & $n$ & $\begin{array}{l}\text { Gonadal weight } \\
(\mathrm{mg})\end{array}$ & $\begin{array}{l}\text { Uterine/seminal } \\
\text { vesicle weight } \\
(\mathrm{mg})\end{array}$ & $\begin{array}{l}\text { Adrenal gland } \\
\text { weight (mg) }\end{array}$ \\
\hline \multicolumn{2}{|l|}{ Tag/hpg experiment } & & & \\
\hline Without T implant & 10 & $1 \cdot 40 \pm 0 \cdot 28$ & $5 \cdot 18 \pm 1 \cdot 13$ & $9 \cdot 34 \pm 0 \cdot 84$ \\
\hline With T implant & 12 & $4 \cdot 03 \pm 0 \cdot 86^{a}$ & $57 \cdot 5 \pm 9 \cdot 05^{c}$ & $6 \cdot 38 \pm 0 \cdot 37^{\mathrm{b}}$ \\
\hline \multicolumn{5}{|l|}{ Males } \\
\hline Without T implant & 10 & $8.37 \pm 1.99$ & $66 \cdot 0 \pm 6 \cdot 00$ & $8 \cdot 28 \pm 0.50$ \\
\hline With T implant & 15 & $133 \cdot 6 \pm 21 \cdot 6^{\mathrm{c}}$ & $799 \pm 168^{b}$ & $5 \cdot 49 \pm 0 \cdot 36^{c}$ \\
\hline \multicolumn{5}{|l|}{ Castrated TG mice } \\
\hline \multicolumn{5}{|l|}{ Females } \\
\hline Without T implant & 9 & & $3 \cdot 08 \pm 1 \cdot 46$ & $9 \cdot 54 \pm 0.94$ \\
\hline With T implant & 16 & & $83 \cdot 1 \pm 13 \cdot 8^{c}$ & $4 \cdot 53 \pm 0 \cdot 16^{c}$ \\
\hline \multicolumn{5}{|l|}{ Males } \\
\hline Without T implant & 8 & & $132 \pm 110$ & $7 \cdot 92 \pm 0.23$ \\
\hline With T implant & 14 & & $670 \pm 135^{b}$ & $4 \cdot 39 \pm 0 \cdot 52^{c}$ \\
\hline
\end{tabular}

a concentration of $0.8 \mathrm{ng} / \mathrm{ml}$ at a sample volume of $25 \mu \mathrm{l}$. The cross-reactivity of the assay was $<0.3 \%$ with rat $\mathrm{LH}$ and $<0 \cdot 06 \%$ with rat growth hormone. Both gonadotropin assays demonstrated parallel dilution curves for mouse serum and pituitary extracts and the respective rat gonadotropin standards (NIH RP-2; results not shown), which was considered evidence for suitability of the assays developed for rat gonadotropins to monitor the same hormones in mouse samples.

Serum levels of testosterone were measured from diethyl ether extract by RIAs, as described earlier (Huhtaniemi et al. 1985).

\section{Histology}

Bouin-fixed paraffin sections ( $5 \mu \mathrm{m}$ thick) of gonads and adrenal glands were stained with hematoxylin/eosin for histological analyses.

\section{Statistical analysis}

A MacIntosh version of the superANOVA program (Abacus Concepts, Inc., Berkeley, CA, USA) was used to perform one-factor analysis of variance, followed by factorial test, Duncan's new multiple range and Fisher's protected LSD post-hoc tests. Because the hormone values were skewed they were analysed using non-parametric Mann-Whitney tests. A $P$ value below 0.05 was chosen as the limit of statistical significance.

\section{Results}

Effect of testosterone implants on gonadal and adrenal tumorigenesis in castrated and hypogonadal TG mice

None of the control or testosterone-treated Tag/hpg mice developed macrocospically discernible gonadal or adrenal tumors. Neither did the testosterone-treated castrated TG mice develop adrenal tumors, whereas histological analysis demonstrated clear adrenal tumors in the castrated, nontreated, control TG mice (see below). Unlike in our earlier studies (Kananen et al. 1996b, Rilianawati et al. 1998), the adrenal tumors detected in the mice had not reached macroscopic stage at the time of killing. The difference from our earlier findings is apparently due to biological variation and slower tumor progression to macroscopic stage in the currently studied groups of mice. The weights of gonads, uteri and seminal vesicles were significantly increased by testosterone in comparison with non-treated animals $(P<0 \cdot 001)$. In contrast, the adrenal weights were significantly reduced by testosterone treatment $(P<0 \cdot 001)$ in all animals (Table 1). Although some differences were found between mean body weights of the different treatment groups, expression of organ weights per body weight did not change the findings (not shown).

\section{Gonadal and adrenal histology}

The histological picture of ovarian sections of the non-treated Tag/hpg females showed complete arrest of folliculogenesis at the primary/secondary stage (Fig. 1A). 

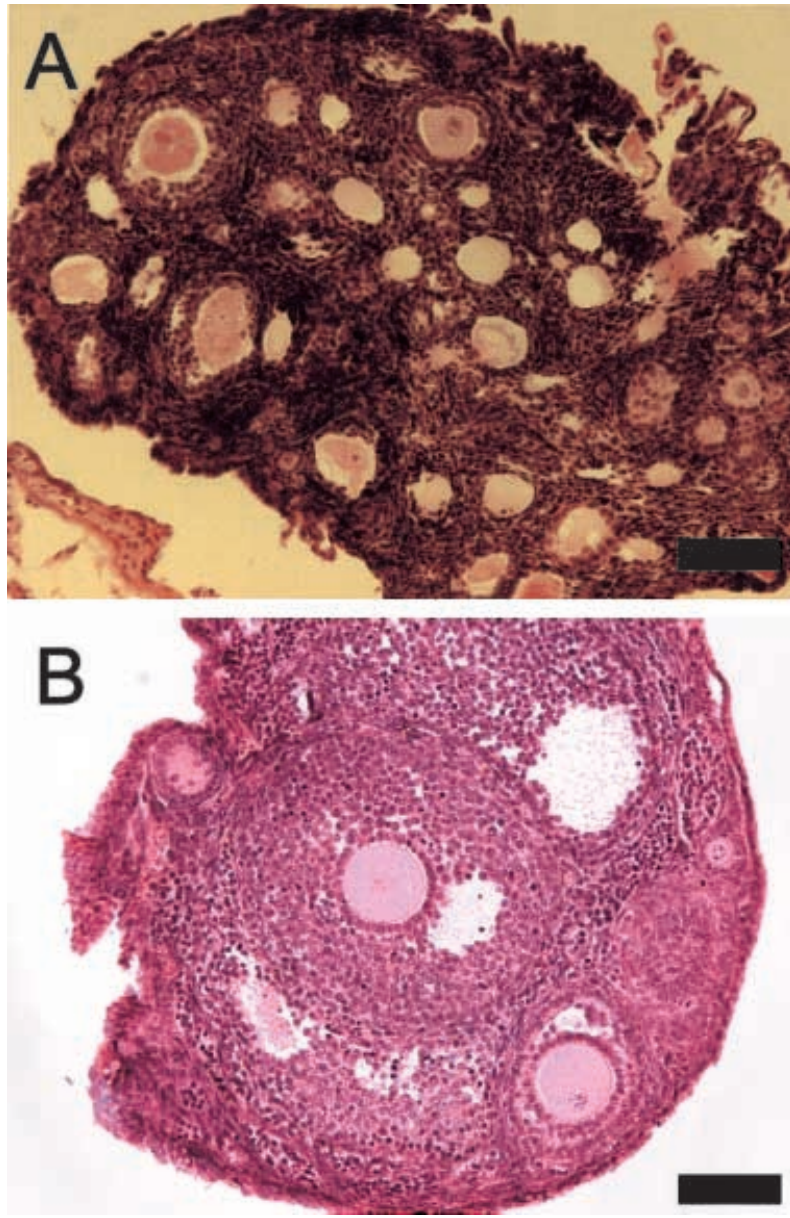

Figure 1 Histological analysis of ovarian tissue of 8-month-old control and testosterone-treated Tag/hpg mice. (A) Ovarian section of a non-treated Tag/hpg mouse showing arrest of follicular development at the stage of primary/secondary follicles. (B) Ovarian section of a testosterone-treated Tag/hpg mouse with development of follicles up to the early antral stage. In addition, stromal hyperplasia is apparent. The bars in the panels are $10 \mu \mathrm{m}$.

More advanced folliculogenesis was observed in the testosterone-treated Tag/hpg mice, up to the early antral stage, but not beyond (Fig. 1B). Surprisingly, stromal hyperplasia was found in the ovaries of the testosteronetreated females. The testes of the non-treated Tag/hpg mice showed complete spermatogenic arrest and lack of development of the interstitial compartment (Fig. 2A). The testosterone-treated Tag/hpg males displayed hyperplasia of testicular interstitial cells, and spermatogenesis was induced, even though only partly (Fig. 2B).

Histological analysis of adrenal glands of the castrated non-treated TG mice showed early stages of tumorigenesis in the cortex (Fig. 3A). It originated from the innermost layer of the adrenal cortex, apparently the X-zone. The non-treated $\mathrm{Tag} / \mathrm{hpg}$ mice, as a consequence of functional gonadectomy, clearly showed persistence of the X-zone,
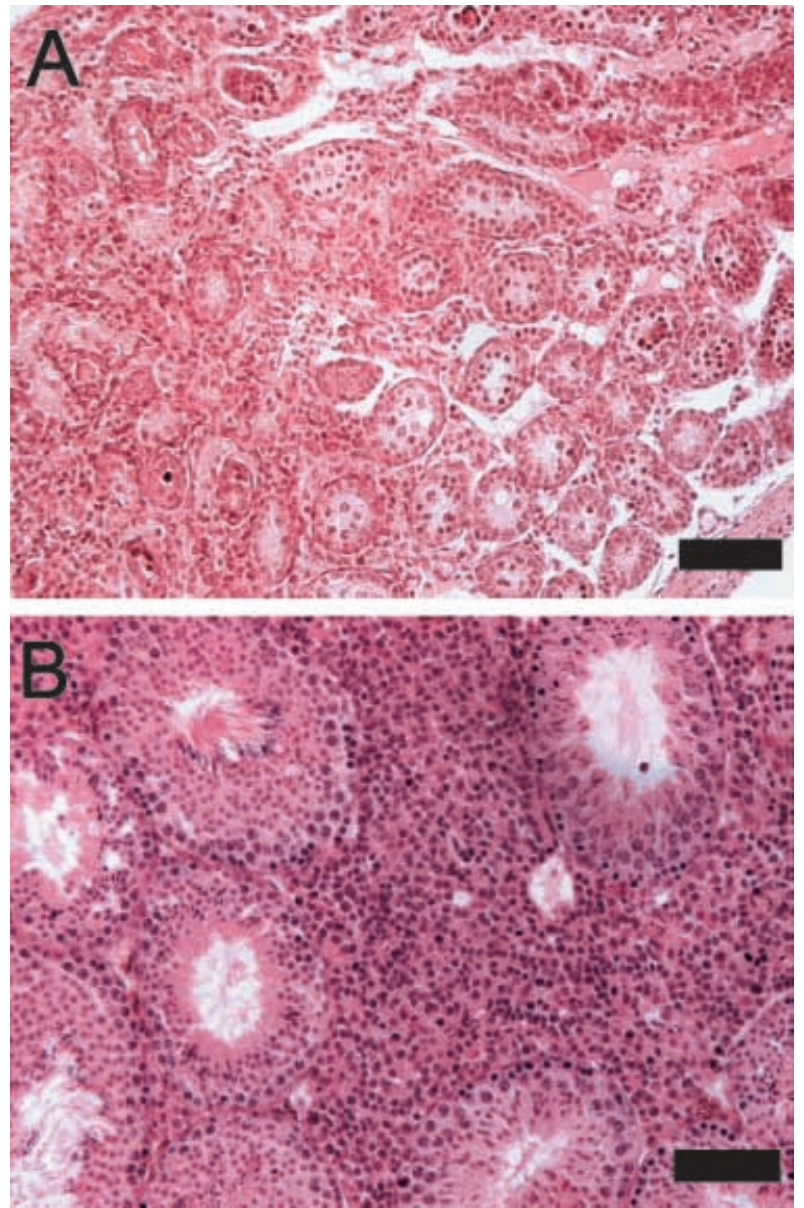

Figure 2 Histological analysis of testis tissue of 8-month-old control and testosterone-treated Tag/hpg mice. (A) Testis section of non-treated Tag/hpg mouse showing arrested spermatogenesis and lack of interstitial cell development. (B) Testis section of testosterone-treated Tag/hpg mouse showing hyperplasia of interstitial cells and induced spermatogenesis. The bars in the panels are $10 \mu \mathrm{m}$.

but no signs of tumorigenesis (Fig. 4A). The medulla was intact in all animals examined. In contrast, in castrated (Fig. 3B) and Tag/hpg (Fig. 4B) mice, testosterone treatment appeared to induce involution of the $\mathrm{X}$-zone, and also the other zones of the adrenal cortex were less distinct. This result indicated that, in the testosterone-treated animals, adrenal tumorigenesis was inhibited.

\section{Pituitary and serum hormone levels}

Testosterone treatment did not affect the pituitary contents of FSH and LH in the Tag/hpg and castrated Tag mice (Tables 2 and 3). Interestingly, the serum levels of FSH in the testosterone-treated Tag/hpg mice were significantly increased in both sexes, whereas, in castrated testosterone-treated males and females, serum FSH was 

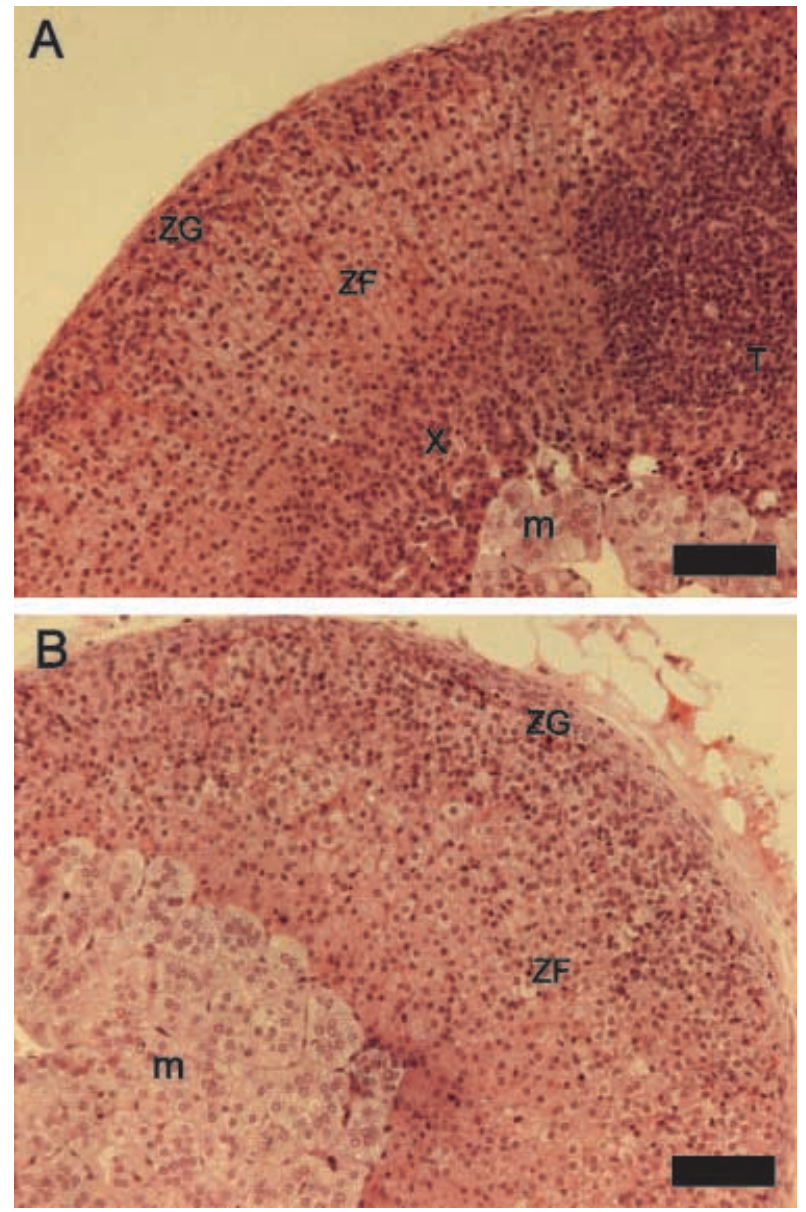

Figure 3 Histological analysis of adrenal glands of castrated non-treated and testosterone-treated TG mice at 8 months of age. (A) Adrenal gland of a non-treated mouse showing early stage of adrenocortical tumorigenesis in the adrenal cortex, apparently arising from the X-zone. (B) Adrenal section of a castrated testosterone-treated TG mouse showing no adrenal tumorigenesis and near-total disappearance of the X-zone. The bars in the panels are $10 \mu \mathrm{m}$. m, medulla; ZF, zona fasciculata; ZG, zona glomerulosa; X, X-zone.

not affected by the steroid implants. However, compared with intact mice (males $11 \cdot 3 \pm 0 \cdot 69$, females $1.22 \pm 1 \cdot 05$ (s.D.) $\mathrm{ng} / \mathrm{ml}$ ), the post-gonadectomy FSH levels were significantly increased. Testosterone did not affect serum $\mathrm{LH}$ in the Tag/hpg mice, whereas in castrated testosterone-treated males and females, these concentrations were significantly reduced. As expected, the testosterone concentration was significantly increased in $\mathrm{Tag} / \mathrm{hpg}$ and castrated testosterone-treated males and females (Tables 2 and 3).

\section{Discussion}

The main aim of the present study was to find out whether testosterone is able to mediate the action of gonadotropins
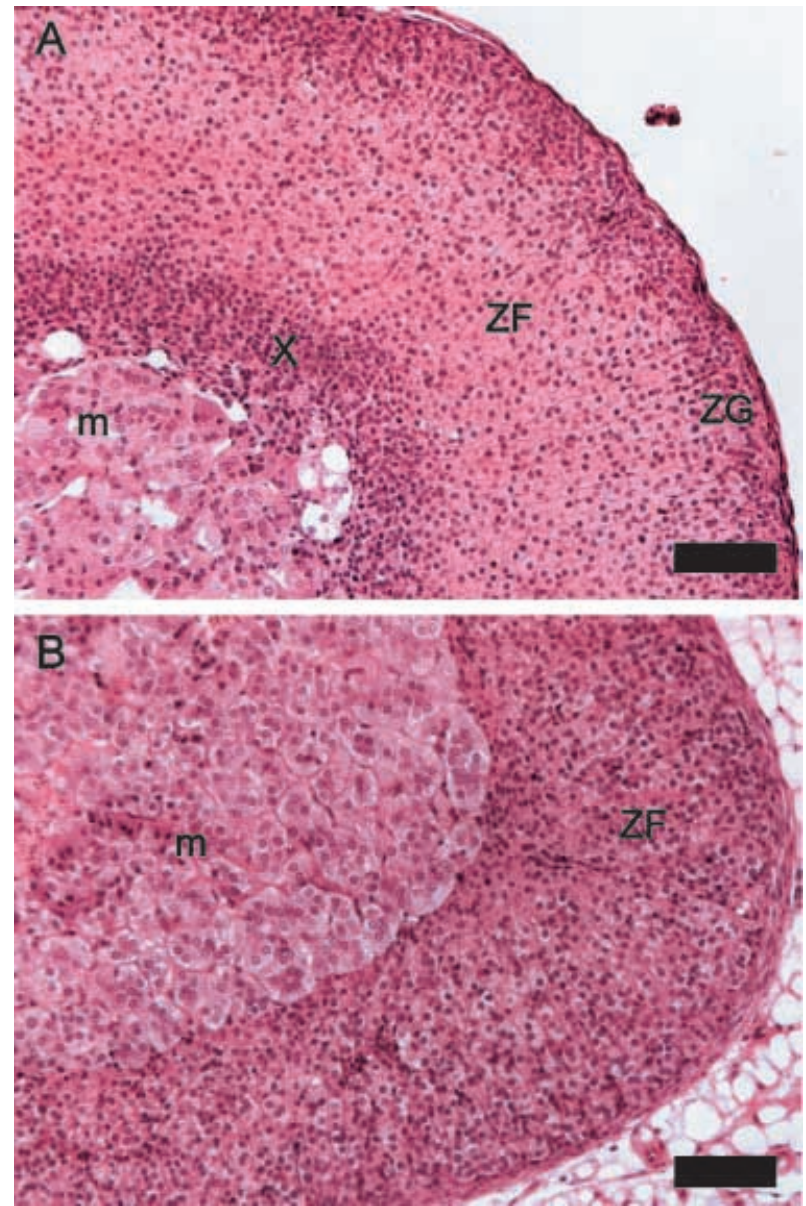

Figure 4 Histological analysis of adrenal glands of control and testosterone-treated Tag/hpg mice at 8 months of age. (A) Adrenal section of a non-treated Tag/hpg mouse showing a prominent X-zone. (B) Adrenal section of a testosterone-treated Tag/hpg mouse, showing disappearance of the X-zone and less clear zonation of the adrenal cortex. The bars in the panels are $10 \mu \mathrm{m}$. $\mathrm{m}$, medulla; X, X-zone; ZF, zone fasciculata; ZG, zone glomerulosa.

in gonadal and adrenal tumorigenesis of the Tag TG mice. In addition, the study further elucidated, in these mice, the inhibition of gonadal and adrenal tumor growth by suppression of gonadotropin secretion. The suppression of gonadotropins by testosterone treatment totally inhibited gonadal and adrenal tumorigenesis in hypogonadal (hpg) and castrated TG mice. The concomitantly elevated testosterone levels demonstrated that increased production of this hormone in response to gonadotropin stimulation is not sufficient to evoke gonadal tumorigenesis of intact TG mice. The tumorigenic effect of high gonadotropin levels is therefore apparently direct.

None of the testosterone-treated Tag/hpg mice developed macroscopically or microscopically detectable gonadal or adrenal tumors. However, the weights of gonads, 
Table 2 Serum (S) concentrations and pituitary (Pit) contents of gonadotropins and testosterone (T) in female mice. Values are median (interquartile range; number of samples analyzed); the number of samples analyzed per group was determined by their availability

\begin{tabular}{|c|c|c|c|c|c|}
\hline & $\begin{array}{l}\text { S FSH } \\
(\mathrm{ng} / \mathrm{ml})\end{array}$ & $\begin{array}{l}\text { Pit FSH } \\
\text { (ng/gland) }\end{array}$ & $\begin{array}{l}\text { S LH } \\
(\mathrm{ng} / \mathrm{ml})\end{array}$ & $\begin{array}{l}\text { Pit LH } \\
\text { (ng/gland) }\end{array}$ & $\begin{array}{l}\mathbf{S ~ T} \\
(\mathrm{nmol} / \mathrm{l})\end{array}$ \\
\hline \multicolumn{6}{|l|}{ Tag/hpg experiment } \\
\hline Without T implant & $<0 \cdot 8(<0 \cdot 8 ; 6)$ & $36 \cdot 2(17 \cdot 6-48 \cdot 7 ; 3)$ & $<0.02(<0.02-0.17 ; 8)$ & $38 \cdot 0(17 \cdot 7-43 \cdot 1 ; 9)$ & $0 \cdot 32(0 \cdot 27-0 \cdot 40 ; 12)$ \\
\hline \multicolumn{6}{|l|}{ Castrated TG mice } \\
\hline Without T implant & $31 \cdot 1(24 \cdot 7-43 \cdot 1 ; 6)$ & $419(179-673 ; 5)$ & $1.03(0.63-6.95 ; 3)$ & $99 \cdot 7(62 \cdot 0-124 \cdot 0 ; 5)$ & $0 \cdot 31(0 \cdot 26-0 \cdot 42 ; 5)$ \\
\hline With T implant & $47 \cdot 3(26 \cdot 3-79 \cdot 2 ; 8)$ & $589(102-665 ; 6)$ & $0 \cdot 13(0 \cdot 09-0 \cdot 14 ; 8)$ & $104 \cdot 0(100 \cdot 0-120 \cdot 0 ; 7)$ & $16 \cdot 7(8 \cdot 15-27 \cdot 9 ; 8)^{\mathrm{b}}$ \\
\hline
\end{tabular}

${ }^{\mathrm{a}} \mathrm{P}<0 \cdot 05,{ }^{\mathrm{b}} \mathrm{P}<0 \cdot 01,{ }^{\mathrm{c}} \mathrm{P}<0 \cdot 001 \mathrm{vs}$ the respective group without $\mathrm{T}$ implant.

Table 3 Serum (S) concentrations and pituitary (Pit) contents of gonadotropins and testosterone (T) in male mice. Values are median (interquartile range; number of samples analyzed); the number of samples analyzed per group was determined by their availability

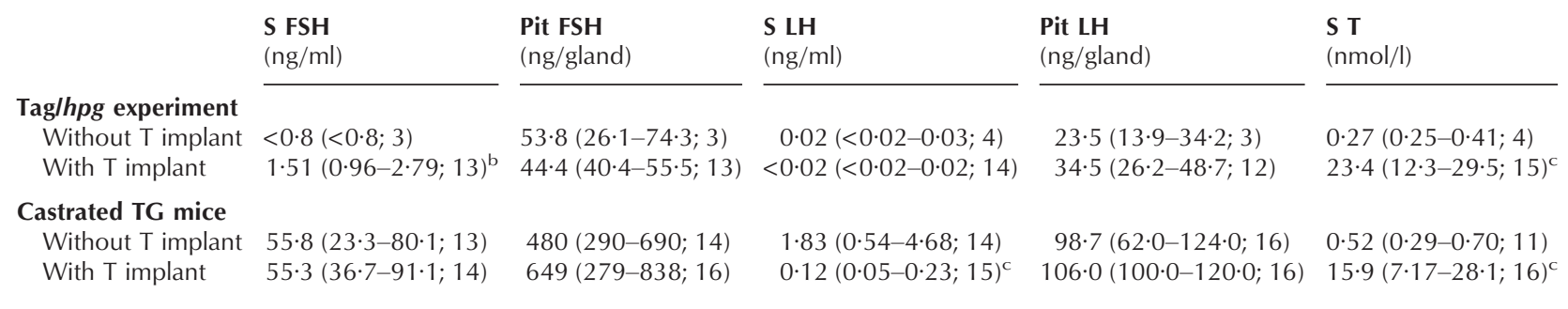

${ }^{\mathrm{b}} P<0 \cdot 01,{ }^{\mathrm{c}} P<0 \cdot 001$ vs the respective group without $\mathrm{T}$ implant.

uteri and seminal vesicles were significantly increased $(P<0 \cdot 001)$, and the testes displayed activation of spermatogenesis. While the effects in the male animals are apparently caused by testosterone, the ovarian and uterine weight increases are best explained by aromatization of a part of the testosterone released from the implants. Gonadal growth response in the testosterone-treated Tag/ hpg mice was caused by stromal hyperplasia in ovaries, and that of interstitial cells and seminiferous tubules in testes. The exact mechanism of these gonadal responses remains unclear since Tag protein could not be detected in the hyperplastic cells (result not shown). It is apparent that, in non-testosterone-treated TG mice, very low levels of the transgene expression, in conjuction with normal or increased gonadotropin action, are able to promote the tumorigenesis (Kananen et al. 1997). The presence of high levels of testosterone can apparently induce hyperplastic changes but not tumor growth, either alone or in synergy with low levels of Tag expression. Hence, the current data are not in support of testosterone-stimulated tumor growth in gonads or adrenals of the TG mice. In contrast, Rajpert-de Meyts \& Skakkabaek (1993) showed that low levels of circulating androgen may contribute to testicular tumorigenesis, whereas high levels of androgen stimulate growth of ovarian tumors (Nash et al. 1989, Godwin et al. 1992). In accordance, ovarian Sertoli-Leydig tumor tissues may produce high levels of testosterone (Abrahamsson et al. 1995). Another study showed that in inhibindeficient/ $t f m$ mutant mice, the androgens are not required for testicular tumor development but may play a regulatory role in tumor progression (Shou et al. 1997).

The serum levels of FSH in testosterone-treated Tag/hpg males and females were significantly increased, while those of $\mathrm{LH}$ were decreased. In contrast, and as demonstrated before (Rodin et al. 1990), the pituitary and serum levels of FSH were unaltered in the castrated mice. This finding suggests that testosterone has a direct stimulatory effect on FSH synthesis and secretion. In vivo and in vitro studies have also shown that testosterone, in the absence of $\mathrm{GnRH}$ stimulation, has a positive effect on FSH gene expression, synthesis and secretion (Gharib et al. 1990, Perheentupa \& Huhtaniemi 1990, Wierman \& Wang 1990). Although testosterone can directly influence the FSH synthesis and secretion, there is more evidence on the role of inhibin as a gonadal feedback inhibitor of FSH secretion. The positive FSH response to testosterone treatment was very similar to that observed in our previous studies with GnRH antagonist- and testosterone-treated rats (Perheentupa et al. 1993a,b). Also, in these animals, testosterone was able to stimulate FSH gene expression, synthesis and secretion, in the absence of apparent changes in serum inhibin levels. Mice with genetically disrupted inhibin $\alpha$-genes showed increased FSH secretion due to the lack of negative feedback of inhibin at the pituitary level. This elevation of serum FSH levels may contribute to, but is not directly responsible for, the development of gonadal tumors in these mice (Matzuk et al. 1994). In accordance, postmenopausal women developing 
ovarian epithelial cancer exhibit increased serum LH and FSH (Godwin et al. 1992). The present results show that testosterone, either alone or in synergy with the slightly elevated FSH levels, may induce hyperplasia in gonadal interstitial cells, but is not able alone to cause tumorigenesis.

There is evidence that testosterone alone, in the absence of FSH, may be sufficient for induction and maintenance of spermatogenesis. Singh et al. (1995) showed that androgen alone in the complete absence of FSH could initiate spermatogenesis in the hypogonadal $(h p g)$ mouse. Some other studies have also demonstrated the same phenomenon in the rat (Ahmad et al. 1973, Awoniyi et al. 1989, 1992). In contrast, there are also studies emphasizing that both testosterone and FSH are needed for maintenance of spermatogenesis in the rat (Santulli et al. 1990, McLachlan et al. 1994). The present study showed that, when spermatogenesis was induced by testosterone treatment in hpg mice, there was a concomitant slight, but significant, increase in FSH secretion. Such an effect has not been detected earlier in studies attempting to induce spermatogenesis with testosterone treatment alone. Although the increase that we observed in FSH levels may not be high enough for major physiological effects, it calls for caution in interpretation of experiments where testosterone alone has been show to induce spermatogenesis.

Previously, we detected adrenal gland tumorigenesis in castrated TG mice at the age of 6-8 months, but not in gonad-intact TG mice, suggesting that the presence of gonadal factors inhibits adrenal tumorigenesis (Kananen et al. 1995). However, the induction of adrenal LH responsiveness after gonadectomy was found to be the mechanism of adrenocortical tumorigenesis (Rilianawati et al. 1998). The suppression of gonadotropins by testosterone showed that adrenal tumorigenesis was inhibited in the absence of elevated gonadotropins. In the present study, the adrenal gland weights were significantly reduced $(P<0 \cdot 001)$ and the $\mathrm{X}$-zone disappeared in the testosterone-treated mice. The adrenocortical tumors appeared to originate from the juxtamedullary $\mathrm{X}$-zone which has been shown to be stimulated by LH and inhibited by androgens (Ungar \& Stabler 1980, Deacon et al. 1986). The X-zone is maintained after gonadectomy and may even reappear in adult male mice after castration (Deacon et al. 1986, Matsuura \& Suzuki 1986). In adrenal tumors of the Tag mice, and in C $\alpha 1$ cells established from an adrenal tumor, co-expression of the $\mathrm{LH}$ receptor and Tag probably form the tumor-promoting mechanism (Rilianawati et al. 1998), and high LH action always seems to be related with the adrenal tumors. In accordance, the present results showed that when serum LH was suppressed by testosterone treatment, adrenal tumor growth was totally inhibited. Accordingly, the high gonadotropin levels after gonadectomy are the most obvious difference between gonadectomized and Tag/hpg mice or GnRH antagonist-treated mice. Although in vitro studies have shown that testosterone stimulates the proliferation of adrenal tumor cell, Ca1 (Rilianawati et al. 1998), the present in vivo study did not show a clear tumorigenic response to testosterone. The present mouse model is similar to the inhibin-deficient mouse model, which develops adrenal tumors after gonadectomy, following increased gonadotropin levels and lack of inhibin (Matzuk et al. 1994). In accordance, adrenal hyperplasia with LH receptor expression appears in TG mice constitutively overexpressing LH (Kero et al. 2000).

In conclusion, the present results suggest that testosterone, alone or in synergy with low levels of FSH, can induce hyperplasia of gonadal interstitial cells in the Tag-expressing TG mice. However, the progression from hyperplasia to tumor growth apparently needs strong $\mathrm{LH}$ action. In the adrenal glands, testosterone, as expected, caused involution of the $\mathrm{X}$-zone, which is the likely origin of adrenal tumors in the Inh- $\alpha /$ Tag mouse model after castration. This response, in conjuction with suppressed LH levels, was apparently responsible for the absence of adrenal tumors in the testosterone-treated mice. The fact that suppression of gonadotropin secretion by testosterone implants inhibits gonadal and adrenal tumor growth excludes gonadotropin-stimulated androgen production as the cause of tumorigenesis.

\section{Acknowledgements}

We thank Dr Pirjo Pakarinen for advice in calculation of the data, and Ms Tarja Laiho and Ms Johanna Vesa for skillful technical assistance. This study was supported by grants from the Sigrid Jusélius Foundation and The Finnish Cancer Foundation.

\section{References}

Abrahamsson G, Dahlen E, Hahlin M, Knutson F, Norström A \& Janson PO 1995 In vitro production of cyclic AMP and steroids from an ovarian Sertoli-Leydig cell tumor. Acta Obstetrica et Gynecologica Scandinavica 74 310-317.

Ahmad N, Haltmeyer GC \& Eik-Nes K 1973 Maintenance of spermatogenesis in rat with intratesticular implants containing testosterone or dihydrotestosterone (DHT). Biology of Reproduction $\mathbf{8}$ 411-419.

Awoniyi CA, Santulli R, Chandrashekar V, Schanbacher BD \& Zirkin BR 1989 Quantitative restoration of advanced spermatogenic cells in adult male rats made azoospermic by active immunization against luteinizing hormone or gonadotropin-releasing hormone. Endocrinology 125 1303-1309.

Awoniyi CA, Zirkin BR, Chandrashekar V \& Schlaff WD 1992 Exogenously administrated testosterone maintains spermatogenesis quantitavely in adult rats actively immunized against gonadotropinreleasing hormone. Endocrinology 130 3283-3288.

Biskin MS \& Biskin GS 1944 Development of tumors in the rat ovary after transplantation into the spleen. Proceedings of the Society for Experimental Biology and Medicine 55 176-179.

Blaakaer J, Baeksted M, Micic S, Albrectsen P, Rygaard J \& Bock J 1995 Gonadotropin-releasing hormone agonist suppression of ovarian tumorigenesis in mice of the $W^{x} / W^{v}$ genotype. Biology of Reproduction 53 775-779. 
van Casteren JJ, Schoonen WGEJ \& Kloosterboer HJ 2000 Development of time-resolved immunofluorometric assays for rat FSH and LH and application on sera of cycling rats. Biology of Reproduction 62 886-894.

Cattanach BM, Iddon CA, Charlton HM, Chiappa SA \& Fink G 1977 Gonadotropin-releasing hormone deficiency in a mutant mouse with hypogonadism. Nature 269 338-340.

Czerwiec FS, Mellner MH \& Puett D 1989 Transiently elevated levels of c-fos and c-myc oncogene messenger ribonucleic acids in cultured murine Leydig tumor cells after addition of human chorionic gonadotropin. Molecular Endocrinology 3 105-109.

Deacon CF, Mosley W \& Jones IC 1986 The X-zone of the mouse adrenal cortex of the Swiss albino strain. General and Comparative Endocrinology 61 87-99.

Gardner WU 1955 Development and growth of tumors in ovaries transplanted into the spleen. Cancer Research 15 109-117.

Gharib SD, Leung PCK, Carroll RS \& Chin W 1990 Androgens positively regulate follicle-stimulating hormone $\beta$-subunit mRNA levels in rat pituitary cells. Molecular Endocrinology 4 1620-1626.

Godwin AK, Perez RP, Johnson SW, Hamaguchi H \& Hamilton GC 1992 Growth regulation of ovarian cancer. Hematology Oncology Clinics of North America 6 829-841.

Haavisto A-M, Pettersson K, Bergendahl M, Perheentupa A, Roser J \& Huhtaniemi I 1993 A supersensitive immunofluorometric assay for rat luteinizing hormone. Endocrinology 132 1687-1691.

Hakola K, van den Boogaart P, Mulders J, de Leeuw R, Schoonen W, van Heyst J, Swolfs A, van Casteren J, Huhtaniemi I \& Kloosterboer H 1997 Recombinant rat follicle-stimulating hormone; production by Chinese hamster ovary cells, purification and functional characterization. Molecular and Cellular Endocrinology 127 $59-69$.

Hogan B, Beddington R, Constantini F \& Lacy E 1994 Manipulating the Mouse Embryo. A Laboratory Manual. Cold Spring Harbor, New York: Cold Spring Harbor Laboratory.

Huhtaniemi I, Nikula H \& Rannikko S 1985 Treatment of prostatic cancer patients with a gonadotropin-releasing hormone agonist analog: acute and long term effects on endocrine functions of testis tissue. Journal of Clinical Endocrinology and Metabolism 61 698-704.

Kananen K, Markkula M, Rainio E-M, Su JGJ, Hsueh AJW \& Huhtaniemi IT 1995 Gonadal tumorigenesis in transgenic mice bearing the mouse inhibin $\alpha$-subunit promoter/simian virus 40 T-antigen fusion gene: characterization of ovarian tumors and establishment of gonadotropin-responsive granulosa cell lines. Molecular Endocrinology 9 616-627.

Kananen K, Markkula M, El-Hefnawy T, Zhang F-P, Paukku T, Su JGJ, Hsueh AJW \& Huhtaniemi I 1996a The mouse inhibin $\alpha$-subunit promoter directs SV 40 T-antigen to Leydig cells of transgenic mice. Molecular and Cellular Endocrinology 119 135-146.

Kananen K, Markkula M, Mikola M, Rainio E-M, McNeilly A \& Huhtaniemi I $1996 b$ Gonadectomy permits adrenocortical tumorigenesis in mice transgenic for the mouse inhibin $\alpha$-subunit promoter/simian virus $40 \mathrm{~T}$-antigen fusion gene; evidence for negative autoregulation of the inhibin $\alpha$-subunit gene. Molecular Endocrinology 10 1667-1677.

Kananen K, Rilianawati, Paukku T, Markkula M, Rainio E-M \& Huhtaniemi I 1997 Suppression of gonadotropins inhibits gonadal tumorigenesis in mice transgenic for the mouse inhibin $\alpha$-subunit promoter/simian virus $40 \mathrm{~T}$-antigen fusion gene. Endocrinology 138 3521-3531.

Kero J, Poutanen M, Zhang F-P, Rahman N, McNicol A-M, Nilson J, Keri R \& Huhtaniemi I 2000 Elevated luteinizing hormone (LH) in transgenic mice induces functional $\mathrm{LH}$ receptor expression and steroidogenesis in adrenal cortex. Journal of Clinical Investigation 105 633-641.

Korkut E, Bokser L, Comaru-Schally AM, Groot K \& Schally AV 1991 Inhibition of growth of experimental prostate cancer with sustained delivery systems (microcapsules and microgranules) of the luteinizing hormone releasing hormone antagonist SB-75. PNAS 88 844-848

Lang J 1991 Assay for deletion in GnRH (hpg) locus using PCR. Mouse Genome 89857.

McLachlan RI, Wreford NG, Tsonis C, de Kretser DM \& Robertson DM 1994 Testosterone effects on spermatogenesis in the gonadotropin-releasing hormone-immunized rat. Biology of Reproduction 50 271-280.

Manetta A, Gamboa-Vujicic G, Paredes P, Emma D, Liao S, Leong L, Asch B \& Schally A 1995 Inhibition of growth of human ovarian cancer in nude mice by luteinizing hormone releasing hormone antagonist cetrorelix (SB-75). Fertility and Sterility 63 282-287.

Matsuura S \& Suzuki K 1986 Morphological changes in the submandibular glands and in the X-zone of the adrenal gland following ovariectomy in mice. Cell and Tissue Research $\mathbf{2 4 6}$ 549-556.

Matzuk MM, Finegold MJ, Su JGJ, Hsueh AJW \& Bradley A 1992 $\alpha$-Inhibin is a tumour-suppressor gene with gonadal specificity in mice. Nature 360 313-319.

Matzuk MM, Finegold MJ, Mather JP, Krummen L, Lu H \& Bradley A 1994 Development of cancer cachexia-like syndrome and adrenal tumors in inhibin-deficient mice. PNAS 91 8817-8821.

Murphy ED \& Beamer WG 1973 Plasma gonadotropin levels during early stages of ovarian tumorigenesis in mice of the $W^{x} / W^{\nu}$ genotype. Cancer Research 33 721-723.

Nash JD, Ozols RF, Smyth JF \& Hamilton TC 1989 Estrogen and anti-estrogen effect on the growth of human epithelial ovarian cancer in vitro. Obstetrics and Gynecology 73 1009-1016.

Parmar H, Phillips RH, Rustin G, Lightman SL \& Schally AV 1988 Therapy of advanced ovarian cancer with D-Trp-6-LHRH (decapeptyl) microcapsules. Biomedicine and Pharmacotherapy 42 531-538.

Perheentupa A \& Huhtaniemi I 1990 Gonadotropin gene expression and secretion in gonadotropin-releasing hormone antagonist-treated male rats: effect of steroid replacement. Endocrinology $\mathbf{1 2 6}$ 3204-3209.

Perheentupa A, Bergendahl M, de Jong FH \& Huhtaniemi I 1993a Differential regulation of FSH and inhibin gene expression and synthesis by testosterone in immature and mature male rats. Journal of Endocrinology 137 69-79.

Perheentupa A, Bergendahl M, de Jong FH \& Huhtaniemi I $1993 b$ Biphasic effect of exogenous testosterone on follicle-stimulating hormone gene expression and synthesis in the male rat. Molecular and Cellular Endocrinology 93 135-141.

Peterson CM \& Zimniski SJ 1990 A long acting gonadotropinreleasing hormone agonist inhibits the growth of a human ovarian epithelial carcinome (BG-1) heterotransplanted in the nude mouse. Obstetrics and Gynecology 76 264-267.

Rajpert-de Meyts E \& Skakkabaek NE 1993 The possible role of sex hormones in the development of testicular cancer. European Journal of Urology 23 54-61.

Rilianawati, Paukku T, Kero J, Zhang F-P, Rahman N, Kananen K \& Huhtaniemi I 1998 Direct luteinizing hormone action triggers adrenocortical tumorigenesis in castrated mice transgenic for the murine inhibin $\alpha$-subunit promoter/simian virus $40 \mathrm{~T}$-antigen fusion gene. Molecular Endocrinology 12 801-809.

Rodin DA, Abbot SD, Saade G \& Clayton RN 1990 Comparison of the pretranslational regulation of FSH synthesis by gonadal steroids in rats and mice. Journal of Molecular Endocrinology 4 159-167.

Santulli R, Sprando RL, Awoniyi CA, Ewing LL \& Zirkin BR 1990 To what extent can spermatogenesis be maintained in the hypophysectomized adult rat testis with exogenously administered testosterone? Endocrinology 126 95-101.

Shou W, Woodruff TK \& Matzuk MM 1997 Role of androgen in testicular tumor development in inhibin-deficient mice. Endocrinology 138 5000-5005. 
Simon WE, Albreght M, Hänsel M, Dietel M \& Hölzel F 1983 Cell lines derived from human ovarian carcinomas: growth stimulation by gonadotropic and steroid hormone. Journal of the National Cancer Institute 70 839-845.

Singh J, O'Neill C \& Handelsman DJ 1995 Induction of spermatogenesis by androgen in gonadotropin-deficient $(h p g)$ mice. Endocrinology 136 5311-5321.

Szepeshazi K, Korkut E, Szende B, Lapis K \& Schally AV 1991 Histological changes in Dunning prostate tumors and testes of rats treated with LH-RH antagonist SB-75. Prostate 18 255-270.

Ungar F \& Stabler TA 1980 20 $\alpha$-Hydroxysteroid dehydrogenase activity and the X-zone of the female mouse adrenal. Journal of Steroid Biochemistry 13 23-28.

Wierman ME \& Wang C 1990 Androgen selectively stimulates follicle-stimulating hormone- $\beta$ mRNA levels after gonadotropin- releasing hormone antagonist administration. Biology of Reproduction $42563-571$.

Yano T, Korkut E, Pinski J, Szepeshazi K, Milovanovic S \& Groot K 1992 Inhibition of growth of MCF-7 MIII human breast carcinomas in nude mice by treatment with agonists or antagonist of LH-RH. Breast Cancer Research and Treatment 21 35-45.

Yano T, Pinski J, Halmos G, Szepeshazi K, Groot K \& Schally AV 1994 Inhibition of growth of OV-1063 human epithelial ovarian cancer xenograft in nude mice by treatment with luteinizing hormone releasing hormone antagonist SB-75. PNAS 91 7090-7094.

Received 8 September 1999

Revised manuscript received 27 January 2000 Accepted 7 March 2000 